\title{
6. 感染症
}

\author{
安 藤 亮 -1 菊 地 勘 ${ }^{2}$ 神田 英一郎 ${ }^{3}$ \\ ${ }^{1}$ 武蔵野赤十字病院腎臟内科 \\ 2 下落合クリニック, 東京女子医科大学腎臟病総合医療センター血液浄化療法科 \\ 3 東京共済病院腎臟内科
}

\section{はじめに}

本稿では，感染症に関する 2014 年の報告について， 重要と思われるものについて紹介する。なお，一部の 報告は 2015 年のものであることをお断りしておく.

\section{I ．透析患者の感染症による死亡}

透析患者は，感染症による死亡が多く，一般人との 比率を検討した報告は以前からある。わが国でも若杉 らにより, 感染症による死は標準化死亡率比で 7.5 倍 とされている。

ERA-EDTA 登録患者（透析患者, 腎移植患者）で 1993２007年に腎代替療法を開始した透析患者 168,156 名を対象として, 2012 年 1 月 1 日までの死亡 を 1,000 患者・年あたりの死亡率と一般住民との死亡 率比に関する報告1)を紹介する，透析患者の感染症に よる死亡率は 30.5/1,000 名・年で, 一般住民との死亡 率比は 82 倍であった。感染症死のうち, 敗血症が 20.2/1,000 名・年, 肺炎が 7.0/1,000 名・年であった. 死亡率は年齢が高くなるにつれて，上昇したが，死亡 率比は逆に，高齢になるにつれて低下した．本邦の報 告と死亡率比とはかなり異なるが, その原因のひとつ として本邦の透析患者の年齢が高いことが関連してい る可能性がある。

\section{II . 透析患者における血流感染, カテーテル関 連感染}

感染症による死亡のなかで, 最も多い血流感染の発 生率を, 1995〜2010 年のデンマークの透析患者 1,792 名とマッチングした一般人 33,618 名と比較した報告 ${ }^{2)}$ がある。透析患者の血流感染発生率は 13.7/100 名・年 で一般人の 14.7 倍であった，特に，透析開始 3 か月以
内は発生率が 48.6/100 名・年であり，一般人の 61.5 倍, 3〜11 か月が 11.7/100 名・年，12 か月以降が 8.23/ 100 名・年と, 透析開始後時間が経つにつれて死亡率 が減少した。 また, 血流感染の起因菌は, 透析患者で は, 黄色ブドウ球菌が $43.8 \%$ と最も多く, 大腸菌は $12.6 \%$ で，一般人とは起因菌の順位が逆であった。 ま た, 血流感染の予後は透析患者では, 黄色ブドウ球菌 は一般人よりも良好であったが，大腸菌では一般人よ りも予後不良であった。

\section{MRSA 保菌について}

透析患者の感染症で問題となることの多いメチシリ ン耐性黄色ブドウ球菌 (methicillin-resistant Staphylococcus aureus : MRSA）保菌に関する 2 つの報告があ る.ひとつは 38 研究 5,596 例のメタアナリシスで検討 した報告3)である。透析患者の MRSA 保菌率は $6.2 \%$ で, CAPD 患者 $(1.3 \%)$ よりも血液透析患者 $(7.2 \%)$ が，外来患者 $(5.4 \%)$ よりも入院患者 $(14.2 \%)$ で高 率であった. MRSA 保菌透析患者は 6〜20 か月の経過 で, 19\%が MRSA 感染症を発症しており, MRSA 非 保菌者からは $2 \%$ であり, リスク比は 11.5 倍であった。

もうひとつは, MRSA 保菌透析患者における5つの $\mathrm{RCT}$ のメタアナリシスの報告 ${ }^{4)}$ で, 2,374 例の透析患者 のうち, $24.6 \%$ MRSA の鼻腔保菌者で, ムピロシン の予防投与により, MRSAによるカテ刺入部感染が $87 \%$ 減少し, MRSA による菌血症が $82 \%$ 減少した.

\section{IV．透析患者の潜在性結核}

透析患者の潜在性結核の感染率をクォンティフェロ ン陽性率から検討した報告5)がある。血液透析患者の クォンティフェロン陽性率は $25 \%$ で, eGFR $30 \mathrm{~mL} / \mathrm{min} /$ $1.73 \mathrm{~m}^{2}$ 未満の保存期慢性腎臓病患者 $(11 \%)$ や透析ス タッフ $(11 \%)$ よりも高かった. 陽性率に関連する因 
表 1 2014 2015 年の Occult HBV の報告

\begin{tabular}{|c|c|c|c|c|c|}
\hline 報告誌・年 & 地域 & 対象透析患者数 - 人 & HBs 抗原陽性・人 $(\%)$ & Occult HBV ·人 $(\%)$ & 備考 \\
\hline Nephrourol Mon. 2014 & イラン & 100 & $0(0 \%)$ & $1(1.0 \%)$ & \\
\hline J Med Virol. 20149) & パレスチナ & 148 & $12(8.1 \%)$ & $16(10.8 \%)$ & $\begin{array}{c}\text { HBc 抗体陽性 } \\
42 / 148(28.4 \%)\end{array}$ \\
\hline Ther Apher Dial. 2015 & 日本 & 161 & $4(2.5 \%)$ & $2(1.3 \%)$ & $\begin{array}{l}\text { HBc 抗体陽性 } \\
43 / 161(26.7 \%)\end{array}$ \\
\hline Hemodial Int. 2015 & ブラジル & 301 & $0(0 \%)$ & $\begin{array}{c}7(2.3 \%) \\
3 / 138(2.2 \%)\end{array}$ & \\
\hline BMC Nephrol. 2015 ${ }^{12)}$ & イギリス & 793 & $15(2 \%)$ & $\begin{array}{l}\text { HBc 抗体陽性患者 } 161 \\
\text { あった } 138 \text { 人の HBV I }\end{array}$ & $\begin{array}{l}\text { 人, 調查可能で } \\
\mathrm{NA} \text { 検査 }\end{array}$ \\
\hline World J Hepatol. 2015 $5^{13)}$ & 総説 & 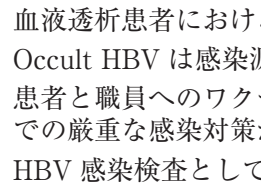 & $\begin{array}{l}\text { occlut HBV 有病率は, } \\
\text { となり得る. } \\
\text { 接種や感染予防の教育 } \\
\text { HBV DNA の検查を施 }\end{array}$ & $\begin{array}{l}\text { 也域や検査方法などによ } \\
\text { occlut HBV を含む HB } \\
\text { すするべき. }\end{array}$ & $\begin{array}{l}\text { 0\%から } 54 \% . \\
\text { 患者への透析室 }\end{array}$ \\
\hline
\end{tabular}

子は, 透析, 年齢, 胸部 X 線の陳旧性病変, アルブミン 值であった，透析患者の潜在性結核のリスクは高く，潜 在性結核の診断にインターフェロン $\gamma$ 遊離試験 (interferon-gamma release assay：IGRA）が有効であるこ と, および潜在性結核に対して積極的に治療すること が, 透析施設における標準的な透析操作と感染予防に 関するガイドライン（四訂版）でも推奨されている.

\section{V．透析患者の肺炎}

透析患者の肺炎に関する報告がわが国から出されて いる ${ }^{6)}$. 対象は 2005 年 10 月から 2013 年 3 月に入院と なった外来維持血液透析患者（全 3,032 例）のうち, CT と臨床症状にて肺炎と診断した 44 例で, 起炎菌は グラム陽性菌, グラム陰性菌ともに $18.2 \%$ ずつで, ク ラミジア $4.5 \%$ ， ウイルス性が $2.3 \%$ と続いた. $25 \%$ は 誤嚥性肺炎で, $31.8 \%$ が起炎菌不明であった. グラム陽 性菌のうち, MRSA が50\%と最も多く, MSSA 25\%, 連鎖球菌 $12.5 \%$, 腸球菌 $12.5 \%$ と続いた。 グラム陰性 菌では, 緑膿菌が $37.5 \%$ と最も多く, 大腸菌 $25 \%$, イ ンフルエンザ菌, モラキセラ菌, クレブジエラがいず れも $12.5 \%$ であった。 また, 喀痰培養の陽性率と提出 のタイミングについても検討し, 透析前が $61.5 \%$ で, 透析後 $16.7 \%$, 透析前日 $36.8 \%$ より高率であった. わが国の透析患者の肺炎の報告であり，特に，喀痰培 養陽性の可能性が透析前で最も高いことを示した.

\section{VI．透析患者におけるインフルエンザワクチン}

インフルエンザワクチンの透析患者における効果を メタアナリシスで検討した報告7)で，インフルエンザ ワクチンは, インフルエンザ流行シーズンの全死亡を
$32 \%$ 減少させ，インフルエンザ/肺炎による死亡を $14 \%$ 減少させた。従来の透析患者へのインフルエンザ ワクチンの効果に関しては, 有効と無効という報告が あったが，その議論にけりをつける論文である。透析 施設における標準的な透析操作と感染予防に関するガ イドライン (四訂版) でも，透析患者に対するインフ ルエンザワクチンの投与を推奨している.

\section{VII. 透析患者におけるウイルス肝炎}

2014 2015 年の透析患者における occult HB 感染 (HBs 抗原院性にもかかわらず, B 型肝炎に感染して いる状態）の報告を表 1 に示した ${ }^{8 \sim 13)}$ 。このうち，本 邦からの報告 ${ }^{10)}$ では, 維持透析患者 161 名中 HBs 抗原 陽性または HBs 抗体陽性または HBc 抗体陽性が 45 例 (28\%) あり，HBV-DNA 陽性が6名（3.7\%）で，こ の 6 名のうち, 4 名は HBs 抗原陽性であるが, 2 名 (1.3\%) が HBs 抗原陰性で, 後者が occult HB 感染で ある。

ガイドラインでも, occult HB感染には触れており, 隔離など感染予防の対象としている.

C 型肝炎に関しては，本邦で行われた多施設共同の $\mathrm{C}$ 型肝炎を有する透析患者に対する PEGインター フェロン治療の報告 ${ }^{14)}$ を紹介する. ウイルスがゲノタ イプ 1 で, ウイルス量が $5.7 \mathrm{LogIU} / \mathrm{mL}$ 未満であれば, 治癒率（SVR）64.3\%, ゲノタイプ 2 では, $6.5 \mathrm{Log} I \mathrm{IU} /$ $\mathrm{mL}$ 未満であれば $87.5 \%$ SVR を得られる。 ガイドラ インでは, インターフェロン治療を推奨しているが, 今後, 後述するインターフェロンを用いない治療が主 流となる見込みである.

$\mathrm{C}$ 型肝炎の治療は, $\mathrm{HCV}$ を直接阻害する薬剤 (Direct Acting Antivirals : DAAs) で透析患者でも使 
用可能なものが開発されてきているという報告 ${ }^{15)}$ があ り, 今後は, インターフェロンを用いない DAAs がC 型肝炎の治療の主流となると考えられる，それに伴っ て, 透析患者の C 型ウイルス肝炎治療ガイドラインも 今後改訂されていくはずである.

\section{VIII. 透析患者におけるその他の感染症}

クロストリジウム・ディフィクルおよびエボラウイ ルスに関する報告がある.

4 研究, 8,214,676 名の CKD 患者のメタアナリシス で, クロストリジウム・ディフィクル感染が, 保存期 CKD 患者の死亡を $73 \%$, 透析患者の死亡を $115 \%$ 増加 させることを示した ${ }^{16)}$.

エボラウイルス（EBV）による急性腎不全の 2 例を 持続的腎代替療法 (continuous renal replacement therapy：CRRT）で治療し，回復したという症例報告 がされた ${ }^{17)}$. EBVによる CRRT 症例に関わった 2 名 の看護師が院内感染をきたした，EBVの血液浄化は CRRTの選択をすることが感染防止および患者管理か らも有利であった。 また, ICUで担当する看護師を最 小限とした．透析液排液にはウイルスは含まれない が, その他の使用した透析器具を廃棄する際には院内 感染防止対策を十分施行する.

\section{おわりに}

透析患者の感染症は古くて新しい問題であるが，患 者の高齢化により重要性はますます増加している．C 型ウイルス肝炎の治療に関しては進歩が著しく, 目を 離せない。

\section{文献}

1) Vogelzang JL, van Stralen KJ, Noordzij M, et al. Mortality from infections and malignancies in patients treated with renal replacement therapy: data from the ERA-EDTA registry. Nephrol Dial Transplant 2015; 30: 1028-37.

2) Dalgaard L, Nørgaard M, Jespersen B. Risk and Prognosis of Bloodstream Infections among Patients on Chronic Hemodialysis: A Population-Based Cohort Study. PLoS One 2015；10：e0124547.

3) Zacharioudakis IM, Zervou FN, Ziakas PD. Metaanalysis of methicillin-resistant staphylococcus aureus colonization and risk of infection in dialysis patients. J Am Soc Nephrol 2014; 25: 2131-41.

4) Grothe C, Taminato M, Belasco A, et al. Screening and treatment for Staphylococcus aureus in patients undergoing hemodialysis: a systematic review and meta-analysis. BMC Nephrol 2014; 15: 202.

5) Shu CC, Hsu CL, Lee CY. Comparison of the Prevalence of Latent Tuberculosis Infection among NonDialysis Patients with Severe Chronic Kidney Disease, Patients Receiving Dialysis, and the DialysisUnit Staff: A Cross-Sectional Study. PLoS One 2015；10：e0124104.

6）佐々木公一, 山口慧, 部坂篤, 他. 維持透析患者にお ける肺炎の起因菌および菌検出の因子の検討. 日腎誌 2014；56：524-31.

7) Remschmidt C, Wichmann O, Harder T. Influenza vaccination in patients with end-stage renal disease: systematic review and assessment of quality of evidence related to vaccine efficacy, effectiveness, and safety. BMC Med 2014; 12: 244.

8) Ramezani A, Aghasadeghi MR, Ahmadi F, et al. Isolated anti-HBc and occult HBV infection in dialysis patients. Nephrourol Mon 2014; 7: e22674.

9) Dumaidi K, Al-Jawabreh A. Prevalence of occult HBV among hemodialysis patients in two districts in the northern part of the West Bank, Palestine. J Med Virol 2014; 86: 1694-9.

10) Saijo $T$, Joki N, Inishi $Y$, et al. Occult hepatitis B virus infection in hemodialysis patients in Japan. Ther Apher Dial 2015; 19: 125-30.

11) Fontenele AM, Gainer JB, da Silva E Silva DV, et al. Occult hepatitis B among patients with chronic renal failure on hemodialysis from a capital city in northeast Brazil. Hemodial Int 2015； 19: 353-9.

12) Sowole L, Labbett W, Patel M, et al. The prevalence of occult hepatitis B virus (HBV) infection in a large multi-ethnic haemodialysis cohort. BMC Nephrol 2015; 16: 12 .

13) Ozer Etik D, Ocal S, Boyacioglu AS. Hepatitis C infection in hemodialysis patients: A review. World J Hepatol 2015; 7: 885-95.

14) Kikuchi K, Akiba T, Nitta K, et al. Multicenter study of pegylated interferon $\alpha$-2a monotherapy for hepatitis C virus-infected patients on hemodialysis: REACH study. Ther Apher Dial 2014; 18: 603-11.

15) Bunchorntavakul C, Maneerattanaporn M, Chavalitdhamrong D. Management of patients with hepatitis C infection and renal disease. World J Hepatol 2015; 27: 213-25.

16) Thongprayoon C, Cheungpasitporn W, Phatharacharukul P, et al. Mortality Risk in Chronic Kidney Disease and End Stage Kidney Disease Patients with Clostridium Difficile Infection: A Systematic Review and Meta-analysis. J Nat Sci 2015; 1: e85.

17) Connor MJ Jr, Kraft C, Mehta AK. Successful delivery of RRT in Ebola virus disease. J Am Soc Nephrol $2015 ; 26: 31-7$. 